\title{
$\boldsymbol{\nabla}$ Artikkeli
}

\section{Suomalaiset sanomalehdet uskonnollisen maiseman tuottajina}

\section{Uskontojournalismi Helsingin Sanomissa, Ilkassa, Kalevassa ja Karjalaisessa vuosina 2007-2011}

\begin{abstract}
Uskonnon ja median tutkimuksen alueella on puhuttu viime vuosina paljon uskonnon aiempaa voimakkaammasta näkyvyydestä länsimaisessa uutismediassa. Erityisesti New Yorkin terrori-iskujen syyskuussa 2001 on katsottu vaikuttaneen siihen, että journalismissa on alettu uudella tavalla kiinnittää huomiota uskontoon. Uskontoon kohdistuvan mediahuomion määrä näyttääkin kasvaneen, mutta selvittämättä on, mistä tarkalleen puhutaan, kun puhutaan uskonnosta journalismissa. Artikkelissa tarkastelemme määrällisesti suomalaista uskontoa koskevaa journalistista kirjoittelua viiden vuoden ajalta neljän sanomalehden osalta. Aineistomme osoittaa, että suomalaisen journalismin tuottama uskonnollinen maisema rakentuu hyvin erillisistä osasista. Lehtien osastot ja journalismin käytännöt tuottavat jaon, joissa paikalliset, valtakunnalliset ja globaalit uskontoa koskevat aiheet pidetään tiukasti erillään. Artikkelin lopussa pohdimme, millainen suhde lehtien tuottamalla uskonnollisella maisemalla on suomalaisen yhteiskunnan uskonnolliseen maisemaan ja uskonnon merkitykseen suomalaisessa yhteiskunnassa.
\end{abstract}

AVAINSANAT: Uskonnollinen maisema, sanomalehdet, ulkomaanuutiset, islam, kristinusko, konflikti

U skonnon uudesta tulemisesta niin median kuin maailmanpolitiikan keskiöön on puhuttu paljon viimeisen vuosikymmenen aikana. Erityisesti Yhdysvaltojen ja Euroopan alueella tapahtuneiden terrori-iskujen on tulkittu vaikuttaneen siihen, että 1960- ja 70-lukujen yhteiskuntatieteellisessä tutkimuksessa jo katoamaan julistettu uskonto on palannut poliittisen keskustelun ja uutisjournalismin keskeisiin aiheisiin (Klausen 2005, 42; Taira ym. 2012; Poole 2002, 5). Toisaalta on huomautettu, ettei uskonto ennustuksista huolimatta ole koskaan poistunut maailmanpolitiikan ja journalismin agendalta. Lisäksi on esitetty, ettei uskonnon tai uskonnollisuuden paluusta jossakin aiemmassa muodossa voida puhua. Uskonto on aiempaa näkyvämmin esillä, mutta sen näkyvyys mediassa on samalla myös aiempaa monimuotoisempaa (Hoelz \& Ward 2008, 1-5.) 
Tutkijoiden piirissä keskustelu uskonnon käsittelystä journalismissa perustuu kuitenkin vielä yllättävän usein teoreettisiin arvioihin ja yksittäisiin tapaustutkimuksiin (esim. Herbert 2011; Hjarvard 2012; Valenzano III \& Menegatos 2008; ks. kuitenkin Taira ym. 2012; Niemelä tässä lehdessä). Tässä tutkimuksessa on analysoitu hyvin laajalla, määrällisellä otannalla sitä, miten uskonto esiintyy suomalaisissa sanomalehdissä ja sen eri uutisosastoissa'. Juttuja neljästä sanomalehdestä Helsingin Sanomista, Ilkasta, Kalevasta ja Karjalaisesta oli yhteensä 16380 vuosilta 2007-2010. Tutkimuksen tavoitteena oli selvittää, millaisen uskonnollisen maiseman suomalainen uutisjournalismi tuottaa.

Uskonnollisen maiseman käsitettä on joissakin aiemmissa tutkimuksissa käytetty melko konkreettisesti kuvaaman tietyn maantieteellisen kokonaisuuden uskonnollisesti erilaisia alueita (esim. Guest 2003, 120-146; Frame 2009). Mediatutkimuksessa maiseman käsitteellä viitataan kuitenkin median tuottamaan diskursiiviseen ja kuviteltuun kokonaisuuteen. Nämä kokonaisuudet ovat symbolisia, visuaalisia ja tekstuaalisia merkitysverkkoja, joiden kautta ympäröivä maailma hahmotetaan. Median tuottamassa globaalissa maisemassa on kansallisia kerrostumia, jotka sitovat yleisönsä tiettyyn paikkaan, mutta samalla tuottavat hyvin rajatun, kansallisen ja paikallisen katseen. (Ks. Appadurai 1990, 296-299; Moring 2001, 167; Morley \& Robins 1995, 10-25.) Kun journalismissa kirjoitetaan uskonnosta, eri uskonnot liitetään toistuvasti tiettyihin paikkoihin, tiettyihin poliittisiin tapahtumiin ja tiettyihin ihmisryhmiin.

Kun tässä artikkelissa analysoimme median tuottamaa uskonnollista maisemaa, tutkimme siis, millaisin aihein ja millaisissa konteksteissa uskonnoista kirjoitetaan ja miten näin rakennetaan lukijoille käsitystä uskonnon tilasta suomalaisessa yhteiskunnassa ja globalisoituvassa maailmassa. Analysoimme, mikä ja missä on uskonnon paikka suomalaisissa sanomalehdissä, millaiset paikat journalismin tuottamassa uskonnollisessa maisemassa näkyvät ja kuinka journalismin maalaamat uskonnolliset maisemat erilaisissa konteksteissa eroavat toisistaan. Tulkitsemme, että maisemaan vaikuttavat niin journalistiset käytännöt, sanomalehtien osastojako kuin tarkasteltavien lehtien ilmestymisaluekin. Valtakunnallisessa lehdessä korostuvat ulkomaanuutiset, kun taas maakuntalehdet kirjoittavat näkyvämmin oman alueensa valtauskonnosta ja seurakuntien paikallisesta toiminnasta. Kaikissa analysoiduissa lehdissä ulkomaansivuilla esiintyy eniten islam, kotimaansivuilla kristinusko. Näistä aineksista rakentuva sanomalehtien tuottama uskonnollinen maisema on varsin pirstaleinen. Eri osastojen tuottamat uskonnolliset maisemat eivät kommunikoi keskenään vaan jäävät pikemminkin erillisiksi saarekkeiksi. Siten uskonnollinen maisema hahmottuu eri tavoin riippuen siitä, mitä uutisia tai osastoja seuraa.

Median ja uskonnon suhteita tarkasteltaessa suomalainen uskontoa koskeva journalismi tarjoaa mielenkiintoisen aineiston. Näyttää siltä, että Suomessa kuten muissa Pohjoismaissa uskonnosta käydään nyt jatkuvaa merkityskamppailua (Ketola 2008, 346-351; Kääriäinen ym. 2003, 137-138, 253-263). Luterilaisuuden itsestään selvä luonne pohjoismaisen ja suomalaisen uskonnollisen maiseman keskeisenä piirteenä on kyseenalaistunut, ja etenkin suurissa kaupungeissa luterilaisuus ei ole enää samalla tavalla osa suomalaista elämäntapaa kuin aiemmin. Julkisuuden agendalla ovat nyt 
yhtä lailla luterilaisen kirkon asema, islamin haaste kuin maallistuminen ja siihen liittyvä uskontokritiikki. (Moberg \& Sjö 2012; Matikainen 2011; Ketola 2008, Kääriäinen ym. 2003.)

\section{Aineisto ja menetelmä}

Tutkimuksessa luokiteltiin määrällisesti uskontoa koskevat jutut neljän sanomalehden uutisosastoista: etusivuilta tai ns. premisivulta, ulkomaan osastosta, kotimaan osastosta ja paikallisuutissivuilta.

Neljä valittua lehteä olivat Helsingin Sanomat, Ilkka, Kaleva ja Karjalainen. Lehdet valittiin siten, että niiden levikkialueet edustaisivat uskonnollisesti erilaisia ympäristöjä. Karjalaisen levikkialueella vaikuttaa ortodoksisuus, kun taas Pohjois-Pohjanmaalla, Kalevan levikkialueella, lestadiolaisuudella on vankka jalansija. Etelä-Pohjanmaalla, jonka maakuntalehti Ilkka on, herännäisyys eli körttiläisyys omaa puolestaan vahvan aseman. Helsingin Sanomat on paitsi valtakunnallinen myös pääkaupungin seudun paikallislehti, ja sen lukijakunnassa on todennäköisimmin uskonnottomia tai muuta kuin kristinuskoa harjoittavia. (Palmu ym. 2012; Niemelä \& Salomäki 2006; Kääriäinen ym. 2003, 203-209; Ketola 2008.)

Valituista lehdistä kaksi, Ilkka ja Karjalainen, kuuluvat samaan yhteistyökoalitioon, Väli-Suomen Mediaan. Käytännössä tämä tarkoittaa sitä, että lehdissä on julkaistu jonkin verran samoja juttuja ja juttukokonaisuuksia, erityisesti ulkomaanosastossa. Koko aineistossa tämä on ongelmallista puhtaasti tilastollisesti tarkasteltuna, sillä aineistossa esiintyy joitakin juttuja kahteen kertaan. Kun tutkimuksemme tavoite kuitenkin on tarkastella kunkin lehden kokonaisuutta, vastaa näiden juttujen koodaaminen kahdesti todellista tilannetta. Sekä Ilkan että Karjalaisen lukijat lukevat samat jutut, ja niiden toistuminen on osa suomalaisen journalismin tuottamaa uskonnollista maisemaa.

Aineisto koottiin viiden vuoden ajalta eli 2007-2011. Keräämisessä käytettiin pääasiassa lehtien omien verkkoarkistojen hakukoneita, mutta tietyin osin hakua täydennettiin manuaalisesti lehtiarkistossa. Hakusanoja oli noin 100. Sanat valittiin siten, että ne tuottaisivat mahdollisimman kattavasti juttuja eri uskonnoista, uskonnollisista suuntauksista ja herätysliikkeistä. Hakusanoihin sisältyi erilaisten uskontotraditioiden ja uskonnollisten suuntausten nimiä, kuten buddhalaisuus, hindulaisuus, katolilaisuus, shiialaisuus ja helluntaiherätys. Myös uskonnon ja uskonnonharjoittamisen erilaisiin tasoihin pyrittiin kiinnittämään huomiota. Hakusanoissa oli mukana eri uskontojen jumalia ja muita uskonnollisia hahmoja (esim. Allah, Jehova, apostoli, pyhimys), uskonnollisia instituutioita, rakennuksia ja virkoja (esim. seurakunta, kirkko, synagoga, moskeija, arkkipiispa, imaami) sekä uskonnollisia kirjakokoelmia (esim. Vanha testamentti, Koraani). Myös vuotuisia ja siirtymäriitteihin liittyviä uskonnollisia juhlia (esim. joulu, ramadan, id al-fitr, hanukka) sisältyi hakusanoihin. Samoin hakusanoihin sisällytettiin uskonnollisia ja uskonnonharjoittamiseen liittyviä käsitteitä, kuten ekumeeninen, lahko, pyhiinvaellus ja rukous. Toisin kuin pohjoismaisessa Norel-projektissa (ks. Niemelä tässä lehdessä) aineistoa kerättäessä ei jaoteltu juttuja sen mukaan, 
oliko niissä varsinaista uskonnollista sisältöä. Aineistoon otettiin mukaan lähes kaikki jutut, joissa uskonnosta kirjoitettiin².

Aineistoa kertyi yhteensä 16380 juttua. Jutut koodattiin käyttäen yhdeksää määrällistä muuttujaa (vuosi, kuukausi, lehti, osasto, juttutyyppi³ ${ }^{3}$ uskontotraditio, uskonnollinen suuntaus ${ }^{4}$, herätysliike ${ }^{5}$, ensisijainen teema).

Teemamuuttujia oli käytössä yhteensä 28. Karkeasti jaotellen teemoja oli kolmen tyyppisiä: vuotuisiin rituaaleihin ja tapahtumiin liittyvät teemat, uskonnon ja politiikan yhteenkietoutumiseen liittyvät teemat sekä kulttuurisiin ja yhteiskunnallisiin aiheisiin liittyvät teemat. Vuotuisiin uskonnollisiin juhliin tai tapahtumiin kirjautuivat esimerkiksi jouluun, ramadaniin tai vanhoillislestadiolaisten suviseuroihin liittyvät jutut. Uskonnon ja politiikan yhteenkietoutumisen teemoihin kuuluivat esimerkiksi valtioiden väliset ja valtioiden sisäiset poliittiset konfliktit, terrorismi sekä uskonnollisen ideologian omaavien poliittisten puolueiden ja poliittisten liikkeiden toiminta. Kolmas ryhmä - kulttuuriset ja yhteiskunnalliset aiheet - sisälsi määrällisesti eniten muuttujia, sillä näihin teemoihin lukeutuivat muun muassa sukupuolten välinen tasa-arvo uskonnoissa, homoseksuaalisuuden asema uskonnoissa, ruumista ja pukeutumista koskevat tavat ja vaatimukset, kirkkopolitiikka, uskonnollisten yhteisöjen yhteiskunnallinen toiminta sekä uskontojen ja valtion suhteeseen liittyvä keskustelu.

Määrällisten muuttujien lisäksi jutuista kirjattiin niiden päivämäärä ja otsikko. Suurin osa jutuista oli uutisia (lehtikohtaisesti vaihdellen $74-83 \%$ ), vaikka aineistoon otettiin mukaan muunkin tyyppisiä juttuja, kuten erikoisartikkeleita, kolumneja ja haastatteluja.

Lehden koko näkyi aineistojakaumassa. Suurimmassa lehdessä, Helsingin Sanomissa, julkaistiin viiden vuoden aikana yhteensä noin 6600 uskontoon liittyvää juttua, kun taas Kalevasta ja Karjalaisesta aineistoa kertyi kummastakin selvästi yli 3000 juttua. Ilkkaa koskeva aineisto jäi alle 3000 jutun, mutta Ilkassa tämä liittyi osittain hakuteknisiin ongelmiin ${ }^{6}$.

\section{Uskonnot valtakunnallisessa ja paikallisessa näkymässä}

Lehtien profiilit suhteessa uskontoon ovat selvästi erilaiset. Suurin osa Helsingin Sanomissa julkaistuista uskontoa käsittelevistä uutisista on ilmestynyt ulkomaanosastossa (64 \%). Tämä selittynee lehden valtakunnallisella profiililla. Helsingin Sanomilla on laajemmat resurssit ulkomaanuutisointiin kuin maakuntalehdillä. Lisäksi maan johtavana sanomalehtenä erityisesti sen tehtävä on välittää kansainvälisiä uutisia maailmalta suomalaisille lukijoille. Helsingin Sanomat oli aineiston ainoa lehti, jossa islamia koskevien juttujen osuus oli hieman suurempi (44\%) kuin kristinuskon (40 \%). Osasyy tähän oli juuri ulkomaanuutisten suuri osuus. Muissa tarkastelluissa lehdissä kristinuskosta kirjoitettiin eniten. Niissä vähintään puolet (noin 50-70 \%) kaikista uskontoa koskevista jutuista käsitteli kristinuskoa.

Islamin suuren osuuden vuoksi Helsingin Sanomien voi väittää olevan profiililtaan poikkeuksellinen, kun sitä verrataan esimerkiksi brittilehdistöön, jossa kristinuskosta 
kirjoitetaan selvästi islamia enemmän (ks. Taira ym. 2012). Kuitenkin myös muissa Pohjoismaissa jako valtakunnallisiin ja alueellisiin lehtiin näkyy myös uskontoa koskevassa kirjoittelussa. Esimerkiksi Norjassa islamin näkyvyys suhteessa kristinuskoon riippuu selvästi siitä, minkälaiselle maantieteelliselle ja samalla uskonnolliselle alueelle lehti on suunnattu (Lundby 2012).

On myös huomattava, että maakuntalehti Kaleva muistuttaa profililtaan valtakunnallista lehteä sikäli, että yli puolet sen uskontoa käsittelevistä jutuista (55 \%) on julkaistu ulkomaanosastossa. Kalevan ja Helsingin Sanomien kristinuskoa ja islamia käsittelevien juttujen osuudet ovatkin hyvin lähellä toisiaan. Niin Helsingin Sanomissa kuin Kalevassa ulkomaan osastojen jutuista suunnilleen $60 \%$ käsitteli islamia ja noin 20 \% kristinuskoa. Tästä huolimatta koko Kalevaa koskevassa aineistossa kristinuskoa koskevilla jutuilla oli suurin osuus, sillä Kalevan muilla osastoissa, eli lehden premisivulla (Tänään/ Uutisaukeama), paikallisuutisissa ja kotimaan osastossa kristinuskolla oli täysin vallitseva asema: 90 \% jutuista käsitteli kristinuskoa. Sen sijaan Helsingin Sanomissa kristinuskon osuus muualla kuin ulkomaan osastossa (premisivu, Kaupunki ja Kotimaan osasto) oli noin 77 \%.

Kaikissa lehdissä uskontoa koskeva kirjoittelu keskittyi siis kristinuskoon ja islamiin. Koko lehtiaineistoa tarkasteltaessa kristinuskoa käsittelevien juttujen osuus oli hieman yli puolet ja islamia käsittelevien juttujen noin reilu kolmasosa jutuista. Muista uskonnoista kirjoitettiin siis korkeintaan vain muutaman prosentin verran juutalaisuudesta ja buddhalaisuudesta eniten.

Siinä missä Helsingin Sanomissa uskontoa koskevasta kirjoittelusta suuri osa liittyi maailmanpolitiikkaan, maakuntalehtien uskontojournalismissa seurattiin aktiivisesti seurakuntien toimintaa sekä osana paikallista kulttuurielämää että seurakuntapolitiikkaan liittyen. Tämän voi päätellä vertailemalla eri lehtien uskontoa koskevan kirjoittelun yleisimpiä teemoja.

Helsingin Sanomissa yleisimmät uskontoon liittyvät teemat ovat ulkopoliittisia aiheita: sisäpoliittiset konfliktit (16\%), terrorismi (8 \%) ja ulkopoliittiset konfliktit (8\%). Myös Kalevassa, jossa puolet jutuista oli ulkomaan uutisia, suurin teemaryhmä kaikista uskontoa käsittelevistä jutuista laskettuna oli sisäpoliittiset konfliktit (11\%). Osuus on kuitenkin hieman pienempi kuin Helsingin Sanomissa. Lisäksi Helsingin Sanomien kolmanneksi suurimman teeman eli ulkopoliittisten konfliktien (7\%) edelle nousi Kalevassa teemaryhmä uskonnollinen kulttuuri ( $8 \%$ ), joka teemaryhmänä sisälsi uskonnollista taidetta ja rakennuksia sekä uskonnollista mediaa koskevat jutut. Valtaosa näistä jutuista liittyi Suomeen, kristinuskoon ja evankelis-luterilaiseen kirkkoon?.

Kaikissa tutkituissa lehdissä kristinuskoa käsittelevistä jutuista selvästi suurin osa, siis 68 prosentista 84 prosenttiin jutuista, sijoittui Suomeen ja liittyi evankelis-Iuterilaisuuteen. Evankelis-luterilaisuuden osuudet olivat hallitsevimmat Ilkassa (76\%) ja Kalevassa (75\%), mutta evankelis-luterilaisuudesta kirjoitettiin kristinuskon suuntauksista selvästi eniten myös Helsingin Sanomissa (62 \%) ja Karjalaisessa (61 \%).

Karjalaisessa yleisin teema uskonnosta kirjoitettaessa oli kirkkopolitiikka (12\%), joka myös on pääosin Suomeen sijoittuva teema. Jutuista 83 \% käsitteli evankelis- 
luterilaisuutta ja $12 \%$ ortodoksisuutta. Toiseksi suurin teemaryhmä Karjalaisessa oli uskonnolliset auktoriteetit (10 \%). Vasta kolmanneksi suurin ryhmä tässä lehdessä oli sisäpoliittiset konfliktit (10 \%), joka Helsingin Sanomissa ja Kalevassa oli yleisin teema. Myös Ilkassa uskontoa koskevassa kirjoittelussa nousi selvimmin esiin kirkkopolitiikka (8\%) ja seuraavina uskonnollinen kulttuuri (8\%) sekä uskonnonharjoittaminen (8\%). Erityisesti Ilkassa näkyy siis uskontoa koskevan kirjoittelun keskittyminen Suomeen ja kristinuskoon.

Teemajaossa näkyy, miten maakuntalehdet edelleen toimivat alueellisina instituutioina, jotka voimakkaasti tuottavat alueellista yhtenäisyyttä. Historiallisesti tarkastellen suomalainen maakuntalehdistö on toiminut ikään kuin "maakuntien äänenä" suhteessa muuhun Suomeen ja ylläpitänyt käsityksiä kulttuurieroista eri alueiden välillä osana kulttuurista pääomaansa. Maakuntalehdistö on luonut kollektiivista alueidentiteettiä tuottaen ja uusintaen alueellisia symboleja. Maakuntalehtien lukeminen on myös perustunut kokemukseen alueellisesta yhteenkuuluvuudesta, ja siksi lehtien asema on perinteisesti ollut melko turvattu lehden sisällöllisistä ratkaisuista riippumatta. Viime aikoina lehdet ovat joutuneet kamppailemaan lukijoistaan enenevässä määrin. Mitä enemmän levikki on laskenut, sitä päättäväisemmin lehdet ovat keskittyneet ydinalueensa tapahtumiin, jolloin aluelehtien uutissisältö on yhä suuremmassa määrin maakunnallista. (Salovaara-Moring 2004, 80-82, 94-95.)

Maakuntalehtien rooli alueellisen yhtenäisyyden tuottajana näkyy myös tarkasteltaessa lehtien esiin nostamia uskonnollisia suuntauksia. Karjalaisessa kristinuskoa koskevista jutuista lähes viidesosa käsitteli ortodoksisuutta, kun muissa lehdissä näiden juttujen osuus vaihteli kahdeksasta prosentista (Helsingin Sanomat) neljään-viiteen prosenttiin (Kaleva ja Ilkka). Ilkassa puolestaan helluntaiherätystä koskevia juttuja oli enemmän kuin muissa lehdissä eli noin 4 \% jutuista. Tähän saattaa olla vaikutusta sillä, että juuri Pohjanmaalla helluntaiherätys on edelleen kasvussa, kun taas muualla Suomessa sen laajeneminen on pysähtynyt ${ }^{8}$.

Toisaalta kaikissa lehdissä ulkomaan uutisten suurehko osuus uskontoa koskevassa kirjoittelussa näkyy siinä, että niin Helsingin Sanomissa, Kalevassa kuin Ilkassa katolilaisuutta ja shiialaisuutta käsiteltiin uskonnollisista suuntauksista enemmän kuin ortodoksisuutta. Tulkitsemme, että ortodoksisuus kuuluu siis suomalaisen journalismin uskonnolliseen maisemaan vain itäisessä Suomessa.

\section{Paikallinen kristinusko: kulttuuria ja kirkkopolitiikkaa}

Hankkeessa tarkasteltujen sanomalehtien näkökulma kristinuskoon on yhtäältä paikallinen ja arkinen, toisaalta hallinnollinen. Suurimmat teemaryhmät kristinuskoa koskevassa kirjoittelussa kaikista lehdistä yhteen laskettuina olivat uskonnollinen kulttuuri sekä kirkkopolitiikka. Näiden teemojen osuus nousi edelleen, kun aineistosta rajattiin erikseen Suomeen sijoittuvat, kristinuskoa käsittelevät jutut. Erityisesti Karjalaisessa kirkkopolitiikan osuus kaikista kristinuskoa käsittelevistä jutuista oli huomattavan suuri (20\%), ja sen osuus nousi edelleen, kun mukaan otettiin vain Suomea 
koskevat jutut (25\%). Varsinkin Ilkassa Suomeen sijoittuvien, kristinuskoa käsittelevien juttujen kiinteä yhteys paikalliseen kulttuurielämään näkyy selvästi, sillä toiseksi eniten Suomen ja kristinuskon yhteydessä kirjoitettiin uskonnollisista tapahtumista.

Myös Helsingin Sanomissa kristinuskoa käsiteltiin uskonnollisen kulttuurin teemaan liittyen. Helsingin Sanomissa tämän teeman osuus oli $12 \%$. Toiseksi yleisin teema oli uskonnolliset auktoriteetit (10\%), joista jutuista hieman yli puolet sijoittui Suomeen.

Taulukko 1: Teemat tutkituissa lehdissä Uskontotraditio: kristinusko, alue: koko maailma

\begin{tabular}{|l|l|l|l|l|}
\hline Teema & HS & Ilkka & Kaleva & Karjalainen \\
\hline Uskonnollinen kulttuuri & $12 \%$ & $11 \%$ & $13 \%$ & $14 \%$ \\
\hline Uskonnolliset auktoriteetit & $10 \%$ & $7 \%$ & $7 \%$ & $12 \%$ \\
\hline Uskonnon ja valtion suhde & $9 \%$ & $8 \%$ & $7 \%$ & $7 \%$ \\
\hline Uskonnollisten yhteisöjen yhteiskunnallinen toiminta & $9 \%$ & $6 \%$ & $9 \%$ & $5 \%$ \\
\hline Kirkkopolitiikka & $8 \%$ & $12 \%$ & $12 \%$ & $20 \%$ \\
\hline Homoseksuaalisuus & $6 \%$ & $4 \%$ & $4 \%$ & $4 \%$ \\
\hline Uskonnonharjoittaminen & $6 \%$ & $10 \%$ & $6 \%$ & $6 \%$ \\
\hline Uskonnollisten yhteisöjen sisällä tapahtuva väkivalta & $5 \%$ & $4 \%$ & $5 \%$ & $4 \%$ \\
\hline Opilliset kysymykset & $5 \%$ & $6 \%$ & $3 \%$ & $4 \%$ \\
\hline Naispappeus & $4 \%$ & $4 \%$ & $4 \%$ & $3 \%$ \\
\hline Uskonnolliset juhlat & $4 \%$ & $5 \%$ & $7 \%$ & $5 \%$ \\
\hline Uskonnolliset tapahtumat & $2 \%$ & $11 \%$ & $7 \%$ & $5 \%$ \\
\hline
\end{tabular}

Taulukossa on esitetty teemat, jotka olivat yleisimpiä useimmissa lehdissä. Kristinuskoon liittyen Helsingin Sanomissa kirjoitettiin uskonnollisia tapahtumia enemmän uskonnollisista poliittisista puolueista (4\%), uskonnollisista perherituaaleista (4\%), sukupuolten tasa-arvosta (3\%), sisäpoliittisista konflikteista (3\%) ja uskonnonvapaudesta (2 \%). Ilkassa kirjoitettiin määrällisesti enemmän uskonnollisten yhteisöjen ja toimijoiden - käytännössä kirkollisten henkilöiden ja seurakuntien merkkipäivistä - kuin naispappeudesta (molempien osuus 4 \%). Myös Karjalaisessa merkkipäivistä kirjoitettiin yhtä paljon (3\%) kuin naispappeudesta. Kalevassa uskonnollisista perherituaaleista (4 \%) kirjoitettiin määrällisesti enemmän kuin opillisista kysymyksistä.

Kun kristinuskoa käsittelevät jutut käsittelivät Suomea ja/tai paikallisia asioita, uskonnollisen taiteen ja kulttuurin osuus nousi Helsingin Sanomissa vielä suuremmaksi (15\%). Vain Suomea koskevia juttuja tarkastellessa uskonnollisten auktoriteettien sijaan toiseksi suurin teemaryhmä oli kirkkopolitiikka (12\%), joten seuratessaan kotimaan ja pääkaupunkiseudun uskontoon kytkeytyviä asioita Helsingin Sanomat toimii kuitenkin alueellisten lehtien tavoin.

Kristinuskosta ja Suomesta kirjoitettaessa kolmanneksi yleisin teema sekä Helsingin Sanomissa että Kalevassa (molemmissa 11 \%) oli uskonnollisten yhteisöjen yhteiskunnallinen toiminta, joka sisälsi esimerkiksi nuorisotoimintaan, diakoniaan, ruokaapuun ja kriisityöhön liittyviä juttuja. Myös evankelis-luterilaisen kirkon edustajien toiminta ja kannanotot pakolaisten käännytyksiä koskevissa asioissa kuuluivat tähän 
ryhmään. Näissäkin jutuissa evankelis-luterilaisen kirkon toiminta Suomessa ja/tai paikallisesti oli keskiössä, ja ne julkaistiin pääosin joko paikallisuutissivuilla tai kotimaan osastossa.

Taulukko 2: Teemat tutkituissa lehdissä Uskontotraditio: kristinusko, alue: Suomi

\begin{tabular}{|l|l|l|l|l|}
\hline Teema & HS & Ilkka & Kaleva & Karjalainen \\
\hline Uskonnollinen kulttuuri & $15 \%$ & $12 \%$ & $15 \%$ & $15 \%$ \\
\hline Kirkkopolitiikka & $12 \%$ & $14 \%$ & $16 \%$ & $25 \%$ \\
\hline Uskonnollisten yhteisöjen yhteiskunnallinen toiminta & $11 \%$ & $6 \%$ & $11 \%$ & $6 \%$ \\
\hline Uskonnon ja valtion suhde & $8 \%$ & $7 \%$ & $5 \%$ & $5 \%$ \\
\hline Uskonnolliset auktoriteetit & $8 \%$ & $6 \%$ & $5 \%$ & $10 \%$ \\
\hline Homoseksuaalisuus & $7 \%$ & $4 \%$ & $3 \%$ & $4 \%$ \\
\hline Naispappeus & $6 \%$ & $4 \%$ & $5 \%$ & $4 \%$ \\
\hline Uskonnolliset juhlat & $5 \%$ & $6 \%$ & $7 \%$ & $5 \%$ \\
\hline Uskonnolliset tapahtumat & $2 \%$ & $13 \%$ & $9 \%$ & $6 \%$ \\
\hline Uskonnonharjoittaminen & $4 \%$ & $10 \%$ & $6 \%$ & $6 \%$ \\
\hline
\end{tabular}

Kristinuskoon ja Suomeen liittyen Helsingin Sanomissa kirjoitettiin uskonnollisia tapahtumia enemmän uskonnollisista perherituaaleista (4 \%), opillisista kysymyksistä (3\%) sekä uskonnollisten yhteisöjen sisällä tapahtuvasta väkivallasta (4\%). Myös Kalevassa homoseksuaalisuutta enemmän kirjoitettiin uskonnollisten yhteisöjen sisällä tapahtuvasta väkivallasta (4 \%). Käytännössä näissä jutuissa käsiteltiin suurimmaksi osaksi lestadiolaisliikkeen sisällä tapahtuneita lasten hyväksikäyttötapauksia sekä liikkeen jäsenten kohtaamaa henkistä painostusta. Karjalaisessa käsiteltiin määrällisesti enemmän opillisia kysymyksiä kuin homoseksuaalisuutta ja naispappeutta (kaikkien osuus $4 \%$ ).

Uskonnollisen kulttuurin teeman yleisyys on siinä mielessä yllättävää, että aineistossa ei ole lainkaan mukana kulttuuriosaston juttuja. Jutut pitävät useimmiten sisällään uutisia kirkkorakennuksista: niin rakentamisesta, remonteista kuin kirkkopaloistakin. Aineistossa raportoitiin erilaisista tihutöistä, kuten hautakivien kaatamisesta ja uskonnollisen esineistön varastamisesta kirkkorakennuksista. Myös pienehköt uutiset kirkkokonserteista sekä kiistat kirkkoon sopivasta musiikista kuuluivat tähän ryhmään. Lisäksi lehdet kirjoittivat melko usein kirkon myönteisestä suhtautumisesta toimintansa laajentamiseen internetiin. Erityisesti Karjalaisessa kirjoitettiin paljon ikoneista, ikonien maalaamisesta, ortodoksisesta kirkkomusiikista, tsasounista sekä ortodoksisen perinteen alueellisesta merkityksestä. Pääsiäisjutuissa ortodoksinen perinne esiintyi usein myös muissa lehdissä.

Kirkkopolitiikkaan kuuluvat jutut puolestaan sisälsivät erilaisia nimitysuutisia ja seurakuntien taloudenhoitoon liittyviä kysymyksiä. Keskeinen osa kirkkopolitiikkakirjoittelua olivat kirkkohallinnon päätöksentekoon liittyvät jutut, kuten kirkollisvaltuustojen päätökset sekä kirkkoneuvostojen, kirkkohallituksen, kirkolliskokouksen ja piispainkokouksen kannat. Myös vaaliuutisointi niin seurakuntavaaleista, kirkkoherran vaaleista, kirkollisvaaleista kuin piispanvaaleista oli näkyvää. Tutkimusajanjaksolle 
sisältyivät evankelis-luterilaista kirkkoa koetelleet kysymykset Luther-säätiön ja Nokia Mission asemasta hallinnollisesti kirkon sisällä, joita tapauksia lehdissä myös seurattiin.

Uutisointi kristinuskosta keskittyy usein instituutioon. Tämä poikkeaa esimerkiksi islam-uutisoinnista. Kirkon toimintaa hallinnollisena organisaationa seurataan säännöllisesti. Kirkolliskokousten päätöksistä ja kirkollisista vaaleista uutisoidaan rutiininomaisesti. Tässä mielessä kirkko uutiskohteena on samankaltainen instituutio kuin poliittiset ja hallinnolliset päätöksentekoelimet, puolueet tai kunnat. Uutisjournalismi ylläpitää evankelis-luterilaisen kirkon asemaa rakenteellisena osana suomalaista yhteiskuntaa, mutta institutionaalisen näkökulman korostuminen samalla osittain häivyttää kirkon roolia uskonnollisena yhteisönä.

\section{Islam: Maailmalla konflikteja, Suomessa monikulttuurisuutta}

Kun uskontotraditioita ja teemoja verrataan keskenään, on selvästi nähtävissä, että kristinusko ja islam esiintyvät lehdissä varsin eri teemojen kautta. Kristinusko asettuu kotoisten kirkkopolitiikan ja uskonnollisen kulttuurin viitekehykseen, kun taas islamin maisema on vähemmän rauhaisa: islam esiintyy ensisijaisesti sisäpoliittisten konfliktien sekä terrorismin yhteydessä. Helsingin Sanomissa, Kalevassa ja Karjalaisessa yli neljäsosa ja Ilkassakin yli viidesosa islamia käsittelevistä jutuista liittyi eri maiden sisäpoliittisiin konflikteihin. Kun mukaan lasketaan terrorismi ja ulkopoliittiset konfliktit, kaikissa kolmessa lehdessä islam kytkeytyy varsin selvästi konflikteihin ja väkivaltaisuuksiin. Helsingin Sanomissa, Kalevassa ja Karjalaisessa yli puolet sekä Ilkassa lähes puolet islamia koskevista jutuista käsittelee joko sisä- tai ulkopoliittisia konflikteja tai terrorismia. Nämä jutut ilmestyivät lähes kaikki ulkomaan osastossa.

Taulukko 3: Teemat tutkituissa lehdissä Uskontotraditio: islam, alue: koko maailma

\begin{tabular}{|l|l|l|l|l|}
\hline Teema & HS & Ilkka & Kaleva & Karjalainen \\
\hline Sisäpoliittiset konfliktit & $28 \%$ & $23 \%$ & $27 \%$ & $26 \%$ \\
\hline Terrorismi & $17 \%$ & $14 \%$ & $14 \%$ & $16 \%$ \\
\hline Monikulttuurisuus & $11 \%$ & $15 \%$ & $14 \%$ & $14 \%$ \\
\hline Ulkopoliittiset konfliktit & $10 \%$ & $11 \%$ & $13 \%$ & $12 \%$ \\
\hline $\begin{array}{l}\text { Uskonnolliset poliittiset } \\
\text { puolueet }\end{array}$ & $8 \%$ & $5 \%$ & $6 \%$ & $5 \%$ \\
\hline
\end{tabular}

Kun mukaan otettiin kaikki islamista kirjoitetut jutut, yleisimmät teemat olivat kaikissa lehdissä samoja.

Islamin liittäminen erilaisiin konflikteihin ei sinällään ole poikkeuksellista länsimaisessa uutisoinnissa. Myös Iso-Britannian lehdistössä islamia koskevissa jutuissa käsitellään pääsääntöisesti terrorismia, ääriliikkeitä ja konflikteja (Taira ym. 2012, 37; 
Elgamri 2008; Petley\&Richardson 2011; Richardson 2004; Poole 2011, 2006 \& 2002). Aiemmassa suomalaisessa islamia koskevaa lehtikirjoittelua koskevassa tutkimuksessa on todettu, että islam harvoin on lehtijutun tärkein aihe: islam esiintyy ennemminkin konfliktiuutisoinnin taustatekijänä. Islam-uutisointia tutkineet Mari Maasilta, Juho Rahkonen ja Pentti Raittila toteavat, että myös tällaiset jutut, joissa islam on taustalla, vaikuttavat lukijoiden käsityksiin islamista. (Maasilta ym. 2008, 19.) On kuitenkin syytä kysyä, onko islamin jäämisellä maininnan asteelle edes merkitystä, kun ajatellaan, minkälaisen kuvan uutisointi islamista tuottaa. Pikemminkin voisi sanoa, että juuri taustoittamaton islamin ja konfliktien jatkuva toisto lehtiuutisissa tuottaa vahvan mielikuvan islamin ja väkivaltaisuuden kytköksestä. Siten myös suomalaisten lehtien tuottamassa uskonnollisessa maisemassa islam esitetään vaarallisena ja uhkaavana.

Islamista piirtyvä kuva ei kuitenkaan ole aivan näin yksinkertainen. Terrorismin ja kriisien lisäksi islamiin liitetään myös monikulttuurisuus, erityisen vahvasti kotimaan uutisoinnissa. Monikulttuurisuusnäkökulma hallitsi kirjoittelua Suomeen sijoittuvissa islamia käsittelevissä jutuissa. Kaikissa neljässä lehdessä suunnilleen puolet (46-54 \%) näistä jutuista liittyi monikulttuurisuuteen. Kaikkiaan niin Helsingin Sanomissa, Kalevassa kuin Karjalaisessa monikulttuurisuusteema oli kolmanneksi yleisin islamia käsittelevissä jutuissa, ja Ilkassa jopa toiseksi yleisin. Myös tässä suhteessa suomalainen islamia koskeva kirjoittelu muistuttaa Iso-Britannian tilannetta (Taira ym. 2012, 37). Aineiston monikulttuurisuusjutut käsittelevät esimerkiksi uskonnollisuuden toteuttamisen ja maallistuneen yhteiskunnan välisiä haasteita, uskonnonharjoittamiseen liittyviä käytännöllisiä kysymyksiä sekä maahanmuuttopolitiikkaa. Uutisointi muistutti näiltä osin kristinuskosta uutisointia arkisena ja kulttuurisena ilmiönä.

Taulukko 4: Teemat tutkituissa lehdissä Uskontotraditio: islam, alue: Suomi

\begin{tabular}{|l|l|l|l|l|}
\hline Teema & HS & Ilkka & Kaleva & Karjalainen \\
\hline Monikulttuurisuus & $46 \%$ & $54 \%$ & $54 \%$ & $52 \%$ \\
\hline Terrorismi & $14 \%$ & $19 \%$ & $13 \%$ & $13 \%$ \\
\hline Uskonnon ja valtion suhde & $9 \%$ & $8 \%$ & $13 \%$ & $5 \%$ \\
\hline Ruumis ja pukeutuminen & $4 \%$ & $6 \%$ & $6 \%$ & $9 \%$ \\
\hline
\end{tabular}

Helsingin Sanomissa ruumista ja pukeutumista enemmän käsiteltiin Suomeen ja islamiin liittyen yksilön mahdollisuutta harjoittaa uskontoaan (5\%) sekä uskonnollisia poliittisia puolueita (5\%) eli käytännössä Suomessa perustettua islamilaista puoluetta, jota johti Abdullah Tammi.]

Maasillan, Rahkosen ja Raittilan tutkimuksessa on analysoitu suomalaisiin muslimeihin liittyviä juttuja. Tutkimuksen mukaan jutuissa esiintyvät muslimit eivät ota kantaa lähtömaansa poliittisiin tapahtumiin vaan pääasiassa kertovat uskonnollisista ja kulttuurisista tavoistaan, usein verraten niitä suomalaisiin tapoihin (Maasilta ym. 2008, 50). Myös meidän tutkimuksessamme aineistoon sisältyvät juttujen otsikot viittaavat siihen, että jutuissa käsitellään nimenomaan kulttuurisia kysymyksiä, joi- 
den käsittelyssä suomalaisuus kansallisena kulttuurina sekä islamilaisuus uskonnollisena identiteettinä asetetaan vertailtavaksi. Tämä näkyy sellaisissa otsikoissa, kuten "Kulttuurit eivät kohtaa kitkattomasti" (Karjalainen 6.2.2008), "Eritaustaiset naapurit riitelevät yhteisistä tiloista ja erilaisista tavoista" (Helsingin Sanomat 23.4.2008), "Normit ja tiedon puute vaikeuttavat musliminaisten liikuntaa" (Ilkka 29.3.2009) sekä "Suomalaisten ryypiskely vaikeuttaa maahanmuuttajien harrastuksia" (Helsingin Sanomat 21.10.2009).

Suomalaisessa lehdistössä islamin käsittely jakaantuu siis kahtia: ulkomaiden konflikti- ja terroriuutisiin sekä kotimaan kulttuurisiin ja sosiaalisiin kysymyksiin. Sanomalehden tiukka jako ulkomaan uutisten, kotimaan uutisten ja paikallisuutisten välillä aiheuttaa sen, että islamilaisissa maissa tapahtuvien poliittisten konfliktien sekä Suomessa asuviin muslimeihin liitettyjen kulttuuristen kysymysten välille ei synny minkäänlaista yhteyttä sanomalehden tuottamassa uskonnollisessa maisemassa. Palaamme tähän teemaan artikkelin lopussa.

\section{Journalismi uskonnollisen maiseman tuottajana}

Lehtien uskonnollinen maisema ei synny tyhjästä eikä tyhjiössä. Journalismin tutkimuksessa journalismi tunnistetaan keskeiseksi yhteiskunnalliseksi voimaksi, joka tuottaa jaettua, julkista kokemusta sekä käsitystä siitä, mikä on todellista ja tärkeää. Journalismia sosiologin katseella tarkasteleva Michael Schudson (2003) korostaa, että journalismi syntyy aktiivisen tuottamisen tuloksena ja tiettyjä lainalaisuuksia noudattaen. Se tuottaa todellisuudesta esityksiä, jotka vaikuttavat päivittäiseen näkemykseen ja käsitykseen maailman tilasta. Journalismia voi siis ajatella kulttuurisena käytäntönä, joka tekee todellisuutta ymmärrettäväksi. Se on merkityksenantoa, todellisuuden luomista, ylläpitämistä ja levittämistä tietynlaisiin periaatteisiin nojautuen. (Ks. esim. Bird 2010, 1, 8; Pedelty 1995; Hannerz 2004; Zelizer 2004; Schudson 2003.) Kun tutkimuksen kohteena on uskonnollisen maiseman tuottaminen sanomalehdissä, on huomio tarkennettava niihin journalistisiin prosesseihin, jotka vaikuttavat maiseman muokkautumiseen. Journalistisista käytännöistä näitä ovat esimerkiksi uutiskriteerit sekä aiheiden ja teemojen jaottelu eri osastoihin.

Viimeaikainen journalismin tuotantoa koskeva tutkimus on jossakin määrin kyseenalaistanut uutiskriteerien merkityksen uutisten syntyä määrittelevänä normistona. Esimerkiksi keskustelu uutisen "merkittävyydestä" on saanut antaa tilaa kysymykselle "kiinnostavuudesta" (Heikkilä ym. 2012). Uutistekstien tarkastelu kuitenkin osoittaa, että uutisten koostumusta määrittelevät selkeät, rutiininomaiset käytännöt. Uutisille tyypillisiä ominaisuuksia ovat tapahtumakeskeisyys, toimintakeskeisyys, henkilökeskeisyys, negatiivisuus, ulkopuolisuus, teknisyys ja virallisuus. (Schudson 2003, 14, 48). Nämä lähtökohdat muokkaavat sitä, mistä aiheesta, missä osastossa, millaisesta näkökulmasta ja miksi aiheesta kirjoitetaan (ks. esim. Goodrum \& Godo 2011).

Tässä tarkastellaan uskonnon käsittelyä sanomalehtien uutissivuilla. Uutisjournalismia puolestaan voidaan hyvästä syystä pitää kaavamaisimpana osana sanomaleh- 
tijournalismia. Erityisen kaavamaista on ulkomaanuutisointi, yksi keskeinen paikka, jossa uskontoa analysoiduissa sanomalehdissä käsiteltiin. Aiemmassa tutkimuksessa on osoitettu, että suuri osa suomalaisten ulkomaansivujen juttumateriaalista tulee uutistoimistoilta, ja tämä koskee myös uskontoa koskevia juttuja. Esimerkiksi Maasilta ym. (2008, 22-23) havaitsivat tutkimuksessaan, että noin puolet islamia koskevista jutuista oli peräisin uutistoimistoilta. Uutistoimistoaineiston käyttö on yksi mekanismi, jonka kautta läntisen maailman käsitykset ja näkemykset kiertyvät itsestään selväksi osaksi suomalaistakin mediamaisemaa.

Brittiläis-australialainen kulttuurintutkija Sara Ahmed puhuu metonymiasta, nimityksenvaihdoksesta, jossa käsitteeseen viitataan nimeämällä toinen, käsitteeseen läheisesti liittyvä käsite. Hänen mukaansa metonymia tuottaa implisiittisen argumentin käsitteiden välisestä kausaalisuhteesta. Esimerkiksi islamin ja terrorismin välille rakennetaan sanomalehdissä syy-seuraussuhde, joka ei näytä edellyttävän eksplisiittistä selittämistä. Metonymian avulla voidaan liittää yhteen asioita silloinkin, kun eksplisiittisesti esitetyt argumentit näyttäisivät pyrkivän erottamaan asioita toisistaan. (Ahmed 2004, 131-132.) Esimerkiksi Ilkan otsikko "Tutkija Turun Sanomille: Tapaus osoitti, ettei terrorismia kannata liittää yksinomaan islamiin" (Ilkka 23.7.2011) purkaa tekstin tasolla kytköstä islamin ja terrorismin välillä, mutta samalla otsikko jälleen yhdistää toisiinsa islamin ja terrorismin. Samoin Ilkassa julkaistu otsikko "Uskonoppinut: Terroristit joutuvat helvettiin" (Ilkka 3.3.2010) purkaa näennäisesti islamin ja terrorismin liitosta, mutta samalla tuottaa islamista uskontona varsin väkivaltaisen kuvan. Helsingin Sanomissa islamin ja terrorismin välinen kytkös kyseenalaistettiin otsikolla "Ovatko kaikki terroristit islamisteja?" (HS 15.12.2010). Samalla otsikko olettaa lukijoidensa lähtökohtaisesti yhdistävän terrorismin islamismiin.

Metonymiat ovat keskeisessä roolissa ulkomaansivujen tuottamassa uskonnollisessa maisemassa. Islamin osalta tuo maisema muistuttaa tippukiviluolaa: terrorismin ja islamin esiintyminen yhdessä juttu jutulta, pisara pisaralta tuottaa lopulta suuria ajatuskalkkeumapylväitä, joita katsoessa islamin ja terrorismin kytkös alkaa näyttää itsestään selvältä ja yhteenkuuluvuus kiveen hakatulta. Väliin jää suuria aukkoja, kuten koko maltillinen, valtavirtainen islamilainen monimuotoisuus. Tällaisessa uutisoinnissa on selvästi nähtävissä vielä Galtungin ja Rugen (1965) uutiskriteereistä odotuksenmukaisuuden kriteeri: islam ja terrorismi kytketään yhteen, koska niiden on totuttu kytkeytyvän yhteen.

Uskonto näyttäytyi sanomalehden uutismaisemassa myös erilaisena riippuen kulttuurisesta paikasta, johon se sijoitettiin. Kotimaisessa maisemassa uskonto esiintyi hyvin erilaisissa konteksteissa kuin ulkomaansivuilla. Kotimaisessa maisemassa näkyvimmälle paikalle nousivat kristilliseen uskonnolliseen kulttuuriin liittyvät aiheet ja teemat. Samoin luterilainen kirkko instituutiona oli vahvasti läsnä. Maisemametaforaa käyttääksemme, kotimaisessa uskonnollisessa maisemassa uskonto näyttäytyi monumenttina: instituutiona ja yhtenä suomalaisen yhteiskunnan rakenteena. Etenkin maakuntalehdissä maisemaan piirtyi monumenttien lisäksi myös uskonnon arkisempia puolia, joita voi kuvata eräänlaisina maiseman yksityiskohtina ja tarkennuspisteinä. 
Sanomalehtijournalismin tuottamaa uskonnollista maisemaa voidaan tarkastella myös siitä näkökulmasta, millä tavoin uskonto näyttäytyy eri maantieteellisissä paikoissa. Tässä maisemassa tietyt maantieteelliset alueet piirtyvät uskonnollisempina kuin toiset. Esimerkiksi Maasillan ym. $(2008,27)$ tutkimuksissa journalismin islam sijoittuu Lähi-itään. Myös oma aineistomme osoittaa, että Lähi-itä muodostaa yhden keskeisimmistä uskonnollisen maiseman tihentymistä tarkastelluissa neljässä sanomalehdessä. Lähi-itään sijoittuvien uskontoa käsittelevien tai sivuavien ulkomaan uutisten voidaan näin tulkita tuottavan uskonnollista maisemaa, jossa uskontoa katsotaan "toisten" maiden, yhteiskuntien ja kulttuurien ominaisuutena. Tälle uskonnolliselle maisemalle luonteenomaisia piirteitä ovat konfliktit ja terrori. Metaforisesti ilmaistuna tällainen maisema on uhkaava ja täynnä vaaroja.

\section{Sanomalehdet uskonnollisen maiseman tuottajana suomalaisessa yhteiskunnassa}

Tutkimuksessamme analysoidun määrällisen aineiston perusteella väitämme, ettei uskonno(i)sta koostu sanomalehtien uutisjournalismissa vain yhtä selkeästi piirtyvää maisemaa, vaan pikemminkin pirstaleinen, mosaiikin kaltainen kokoelma erilaisia näkökulmia ja sävyjä. Kuvan muodostuminen riippuu siitä, mistä kulmasta sitä katsoo. Kuvaan vaikuttavat maailman tapahtumat, osastot joilla uskontoa käsitellään sekä journalistiset käytännöt, jotka muokkaavat näitä käsittelytapoja. Lehden ilmestymisalue ja lehtikohtaiset preferenssit vaikuttavat siihen, millaiset tapahtumat uutisvirrasta päätyvät lehden sivuille ja millaisilla painotuksilla. Aineisto näyttäisi antavan viitettä siihen, että yhtäältä lehden tapa kirjoittaa uskonno(i)sta uusintaa vallitsevaa käsitystä levikkialueella vallitsevasta uskonnollisesta maisemasta. Yksinkertaistettuna: otannan perusteella Helsingin Sanomien oletettu lukijakunta on uskonnollisesti moniarvoisempi ja pirstaleisempi kuin Ilkka-lehdessä, jossa kristinusko yhä näyttää yhteisön yhdessä jakamalta arvopohjalta. Toisaalta islamin saama näkyvä terrorismiin ja konflikteihin liittyvä julkisuus muokkaa käsitystä vieraasta, "toisesta" ja ulkopuolelta meidän arkeemme tunkeutuvasta väkivaltaisesta uskonnosta.

Journalismia ja sanomalehtiä tehdään aina tietynlaisessa maailmassa. Niinpä on kysyttävä, millä tavoin lehtien tuottama uskonnollinen maisema tai maisemat ovat suhteessa uskonnon yhteiskunnalliseen merkitykseen ja paikkaan suomalaisessa yhteiskunnassa laajemmin. Uskonnon paikka ja merkitys monissa länsimaisissa joukkoviestimissä näyttäisi olevan jollakin tapaa liikkeessä, ja tähän on herätty myös uskonnon ja median tutkimuksessa. Omassa tutkimuksessamme meitä yllätti aineiston runsaus: yli 16 ooo tuhatta juttua viiden vuoden ajalta neljässä suomalaisessa sanomalehdessä on paljon. Samoin islamin vahva läsnäolo aineistossa herätti monenlaisia kysymyksiä esimerkiksi siksi, että aineiston määrä ei lainkaan suhteudu Suomessa asuvan muslimiväestön määrään, joka edelleen on vain prosentti koko väestöstä (Martikainen 2008, 71-73). Tulos oli yllättävä myös suhteessa aiempaan tutkimukseen. Esimerkiksi Niemelän tutkimuksessa (ks. artikkeli tässä lehdessä), jossa 
tarkasteltiin vain sellaisia juttuja, joissa oli uskonnollista sisältöä, islamin osuus oli hyvin pieni, vain $3 \%$.

Median tuottama uskonnollinen maisema ja Suomen tilastoissa piirtyvä uskonnollinen maisema näyttävät hahmottuvan islamin osalta siis varsin eri tavoin. Lisäksi ulkomaanuutiset kytkevät metonyymisesti islamin terrorismiin ja konflikteihin. Tämä herättää pohtimaan lehtien lukijakuntaa. Kenen todellisuutta maisemat puhuttelevat ja millä tavoin? On syytä pohtia, millaista mielenmaisemaa ja suhdetta islamiin maailmankatsomuksena ja identiteettinä tällainen toiston politiikka tuottaa. Kuvaa kärjistää edelleen se, että vaikka eri osastoilla uskontoja käsitellään myös eri näkökulmista, eivät osastot kommunikoi keskenään. Näin lehtien tuottamat uskonnolliset maisemat jäävät sirpaleisiksi ja jäsentymättömiksi.

Neljän suomalaisen sanomalehden maalaama kuva uskonnosta on hajanainen. Tätä hajanaisuutta voi yrittää ymmärtää ja tulkita eri lähtökohdista. Yksi mahdollisuus on ajatella uskontoa ilmiönä, jota on mahdotontakin tarkastella yhtenä kokonaisuutena. Uskonto yläkäsitteenä on ongelmallinen jo siitä syystä, että maailman eri uskonnot eroavat monin tavoin toisistaan. Tässä katsannossa maisema ei voikaan olla kovin yhtenäinen. Aineiston pohjalta on kuitenkin ilmeistä, ettei uskontojournalismi erityisesti pyri valottamaan uskontojen moninaisuutta vaan pikemminkin toistaa yhdenlaista näkökulmaa yhden uskontotradition kohdalla ja toisenlaista toisen kohdalla. Toiseksi onkin tarkasteltava sitä, mikä ja millainen uskonto tai millaiset osa-alueet uskontoon liittyen ylittävät uutiskynnyksen ja millainen taas jää huomiotta. Esimerkiksi maailman suurinta islamilaista valtiota Indonesiaa ei juuri mainita, koska sieltä on harvoin tarjolla terrorismiuutisia.

Kolmanneksi on muistettava uskonnon ja uskonnollisuuden määrittelyn kulttuurija historiasidonnaisuus. Se, mikä ylimalkaan tunnistetaan ja tunnustetaan uskonnoksi, muuttuu aikojen saatossa, ja tähän määrittelyyn journalismi ottaa merkittävällä panoksella osaa. Journalismilla on siis valta määritellä, millaisia ilmiöitä kutsutaan uskonnoiksi ja milloin käytetään muita ilmauksia. Ei-institutionaalisten uskonnollisuuden muotojen (kuten luonnonuskontojen tai erilaisten maailmankatsomusten) näkymistä mediassa on vaikeaa edes tutkia, koska media ei niitä uskonnoksi nimeä.

Tässä tutkimuksessa olemme keskittyneet uskontojournalismiin neljässä sanomalehdessä. Tätä nykyä sanomalehtijournalismin rooli uskonnollisen maiseman määrittelyssä on kuitenkin varsin rajallinen. Muiden mediateknologioiden ja mediatekstien läpitunkeva läsnäolo kaikkialla länsimaisessa arjessa vaikuttaa yhä suurempien ihmisjoukkojen käsityksiin uskonnosta. Uskonnollisten instituutioiden ja yhteisöjen mahdollisuus määritellä näitä käsityksiä on samalla tapaa rajallinen kuin sanomalehtienkin. Tulevaisuudessa uskonnon ja median suhteiden tarkastelun näkökulmaa tulisikin laajentaa sanomalehtijournalismin ulkopuolelle, visuaaliseen ilmaisuun, liikkuvaan kuvaan ja sosiaalisen median maailmaan. 


\section{Kirjallisuus}

Ahmed, Sara (2004). Affective economies. Social Text: 22: 2, 118-139.

Appadurai, Arjun (1990). Disjuncture and difference in the global cultural economy. Teoksessa: Mike Featherstone (toim.). Global culture: Nationalism, globalization and modernity. London: Sage, 295-311.

Bird, Elizabeth S. (2010). The anthropology of news and journalism: Why now? Teoksessa: Bird, Elizabeth S. (toim.). The anthropology of news Q journalism: Global perspectives. Bloomington: Indiana University Press, 1-18.

Elgamri, Elzain (2008). Islam in the British broadsheets: The impact of orientalism on representations of Islam in the British press. Reading: Ithaca.

Frame, Tom (2009). Losing my religion: Unbelief in Australia. Sydney: UNSW Press.

Galtung, Johan \& Ruge, Mari Holmboe (1965). The structure of foreign news. Journal of Peace Research 2: 1, 64-91.

Guest, Kenneth J. (2003). God in Chinatown: Religion and survival in New York's evolving immigrant community. New York, USA: New York University Press.

Goodrum, Abby \& Godo, Elizabeth (2011). Elections, wars, and protests? A longitunal look at foreign news on Canadian television. Canadian Journal of Communication 36: 3, 455-475.

Hannerz, Ulf (2004). Foreign news: Exploring the world of foreign correspondents. Chicago: University of Chicago Press.

Heikkilä, Heikki; Ahva, Laura \& Siljamaa, Laura (2012). Kelluva kiinnostavuus. Vastapaino: Tampere.

Herbert, David E.J. (2011). Theorizing religion and media in contemporary societies: An account of religious 'publicization'. European Journal of Cultural Studies 14: 6, 626-648.

Hjarvard, Stig (2012). Three forms of mediatized religion: Changing the public face of religion. Teoksessa: Hjarvard, Stig \& Lövheim, Mia (toim.). Mediatization and religion: Nordic perspectives. Göteborg: Nordicom, 21-44.

Hoelz, Michael \& Ward, Graham (2008). Introduction. Teoksessa: Hoelzl, Michael \& Ward, Graham (toim.) New visibility of religion: Studies in religion and cultural hermeneutics. London: Continuum, 1-15.

Ketola, Kimmo (2008). Uskonnot Suomessa: Käsikirja uskontoihin ja uskonnollistaustaisiin liikkeisiin. Kirkon tutkimuskeskuksen julkaisuja 102. Tampere: Kirkon tutkimuskeskus.

Kääriäinen, Kimmo; Niemelä, Kati \& Ketola, Kimmo (2003). Moderni kirkkokansa: Suomalaisten uskonnollisuus uudella vuosituhannella. Kirkon tutkimuskeskuksen julkaisuja 82. Tampere: Kirkon tutkimuskeskus.

Klausen, Jytte (2005). Islamic challenge: Politics and religion in Western Europe. Oxford: Oxford University Press.

Lundby, Knut (2012). Methodological challenges studying mediatized religion in Nordic newspapers. Presentation at the Nordic Network for Media and Religion Seminar, Sigtuna, Sweden 31.10.2012.

Maasilta, Mari; Rahkonen, Juho \& Raittila, Pentti (2008). Islam suomalaisissa joukkoviestimissä. Tiedotusopin laitos. Julkaisuja A 103. Tampere: Tampereen yliopisto.

Matikainen, Janne (2011). Verkkokeskustelua homoillasta - osallistumisen kulttuuria? Media ja viestintä 34: 1, 92-98.

Martikainen, Tuomas (2008). Muslimit suomalaisessa yhteiskunnassa. Teoksessa:

Martikainen, Tuomas; Sakaranaho, Tuula \& Juntunen, Marko (toim.). Islam Suomessa: Muslimit arjessa, mediassa ja yhteiskunnassa. Helsinki: Suomalaisen Kirjallisuuden Seura, 62-85.

Moberg, Marcus \& Sjö, Sofia (2012). The Evangelical Lutheran Church and the media in post-secular Finland. Teoksessa: Hjarvard, Stig \& Lövheim, Mia (toim.). Mediatization and religion: Nordic perspectives. Göteborg: Nordicom, 77-89.

Moring, Inka (2001). Space and politics of identity: Imaginary landscapes and ideological reproduction of "we". Teoksessa: Kivikuru, Ulla-Maija (toim.). Contesting frontiers: Media and dimensions of identity. Göteborg: Nordicom, 165-187.

Moring-Salovaara, Inka (2004). Media geographies: Regional newspaper discourses in Finland in the 1990 . Department of Communication. Viestinnän julkaisuja 9. Helsinki: Helsingin yliopisto.

Morley, David \& Robins, Kevin (1995). Spaces of identity: Global media, electronic landscapes and cultural boundaries. London: Routledge.

Niemelä, Kati \& Salomäki, Hanna (2006). Herätysliikkeet 200o-luvun kirkollisessa kentässä. Teologinen aikakauskirja 111: 4, 359-371. 
Palmu, Harri; Salomäki, Hanna; Ketola, Kimmo \& Niemelä, Kati (2012). Haastettu kirkko: Suomen evankelisluterilainen kirkko vuosina 2008-2011. Tampere: Kirkon tutkimuskeskus.

Pedelty, Mark (1995). War stories: The culture of foreign correspondents. New York: Routledge.

Petley, Julian \& Richardson, Robin (toim.) (2011). Pointing the finger: Islam and Muslims in the British media. Oxford: Oneworld Publications.

Poole, Elizabeth (2011). Change and continuity in the representation of British Muslims before and after 9/11: The UK context. Global Media Journal: Canadian Edition 4: 2, 49-62.

Poole, Elizabeth (2002). Reporting Islam: Media representations and British Muslims. London: I.B.Tauris.

Poole, Elizabeth (2006). The effects of September 11 and the war of Iraq on British newspaper coverage. Teoksessa: Poole, Elizabeth \& Richardson, John E. (toim.). Muslims and the news media. London: I.B. Tauris, 89-103.

Richardson, John E. (2004). (Mis)Representing Islam: The racism and rhetoric of British broadsheet newspapers. Discourse approaches to politics, society and culture: vol. 9. Amsterdam/Philadelphia: John Benjamin's Publishing Company.

Schudson, Michael (2003). The sociology of news. New York: W. W. Norton.

Taira, Teemu; Poole, Elizabeth \& Knott, Kim (2012). Religion in the British media today. Teoksessa: Mitchell, Jolyon \& Gower, Owen (toim.). Religion and the news. Farnham: Ashgate, 31-43.

Valenzano III, Joseph M \& Menegatos, Lisa (2008). Benedict the bifurcated: secular and sacred framing of the Pope and Turkey. Journal of Media and Religion 7: 4, 207-230.

Zelizer, Barbie (2004). Taking journalism seriously: News and the academy. New York: Sage.

\section{Viitteet}

$1 \quad$ Aiemmin on tutkittu erityisesti islamin käsittelyä suomalaisessa journalismissa, mutta tutkimus eroaa tästä tutkimuksesta islamiin keskittymisen lisäksi siten, että tutkimuksen otantaan oli valittu ajallisesti vain yksi viikko helmikuussa 2007 (ks. Maasilta ym. 2008).

2 Joissakin tapauksissa juttu rajattiin aineiston ulkopuolelle huolimatta hakusanan esiintymisestä jutussa. Esimerkiksi tapauksissa, joissa mainittiin kristillisdemokraatit osana hallitusneuvotteluja, juttu saatettiin rajata ulos, koska kristillisdemokraattisen puolueen uskonnollinen tausta ei ollut jutussa esillä. Sen sijaan, jos juttu käsitteli kristillisdemokraattien kannanottoa homoseksuaalisuuteen suhteessa kristillisiin arvoihin, juttu sisällytettiin aineistoon.

3 Juttutyypeiksi oli määritelty uutinen, erikoisartikkeli, haastattelu, kolumni sekä muu juttu.

$4 \quad$ Uskonnollinen suuntaus koodattiin, jos se oli jutussa mainittu.

5 Herätysliike koodattiin, jos sellainen oli jutussa mainittu.

$6 \quad$ Ilkan verkkohaku oli yksinkertainen eikä hakusanan lisäksi voinut esimerkiksi tehdä aikarajausta. Lisäksi haku näytti vain ensimmäiset sata tulosta, jolloin paljon osumia tuottavasta hakusanasta (kuten islam) hakukone näytti vain sata viimeisintä hakua vastaavaa uutista eikä lainkaan niitä, jotka oli julkaistu tarvitsemanamme ajankohtana 2007-2011 eli aikaisemmin kuin tänä vuonna. Ongelmaa yritettiin pienentää tekemällä useita tarkkoja hakuja paljon tuloksia tuottavan hakusanan eri sijamuodoista, esimerkiksi "islam", "islamin", islamista", jolloin islamia koskevaa aineistoa saatiin kartutettua. Tästä huolimatta Ilkan osalta aineisto on lähinnä suuntaa antava.

7 Kalevassa tähän teemaan koodatuista jutuista 83 \% liittyi evankelis-luterilaisuuteen ja 8 \% ortodoksisuuteen.

8 "Helluntaiherätys pieneni hieman pitkästä aikaa". Seurakuntalainen 27.12.2012. http://www.seurakuntalainen.fi/uutiset/kotimaa/3044/helluntaiheratys_pieneni_hieman_pitkasta_ aikaa. Linkki tarkistettu 1.3.2013. 